\title{
Recovery Rate of Depleted Range Sites Under Protection from Grazing ${ }^{1}$
}

\section{A. MCLEAN AND E. W. TISDALE}

Ecologist, Canada Department of Agriculture, Kamloops, B.C. and Professor of Range Management, University of Idaho, Moscow.

\section{Highlight}

It is estimated to take from 20 to 40 years for overgrazed ranges in the rough fescue and ponderosa pine zones to recover to excellent range condition when fully rested. Little change in plant composition took place inside exclosures, placed on poor condition range, in less than 10 years following fencing. It took longer for the sites to progress from poor to fair condition than from fair to good condition. The main plants to increase with protection were bluebunch wheatgrass and rough fescue. The main species to decrease were Sandberg bluegrass, low pussytoes, and rabbitbrush.

Data on the number of years rest necessary for recovery of range types after depletion from grazing in the Pacific Northwest are meager. Such information would be valuable in assessing the relative merits of resting vs. seeding for range improvement, and of grazing rotations and related management practices.

In southern British Columbia a number of exclosures to exclude livestock were constructed on depleted ranges, mostly during the 1930's, by staff of the Canada Department of Agriculture Research Station, Kamloops, and the British

${ }^{1}$ Received May 8, 1971.
Columbia Forest Service (Fig. 1). The senior author has been observing these exclosures since 1948, while the junior author was active in range research in the area during the period 1935-1947 and established three of the exclosures. Information gathered at the time of fencing varied from general observations and species lists to establishment of permanent quadrats. In most instances, however, the number of quadrats was too few to provide a statistically significant sample, so these data have simply been used to supplement other observations. Most exclosures were visited periodically from the time of fencing until 1959, and observations made on the vegetation.

In 1959 and 1960 the vegetation was sampled inside and outside of these exclosures using the canopycoverage technique (Daubenmire, 1959). The canopy cover class of each species of herb and small shrub was recorded in 50 frames (20 by $50 \mathrm{~cm}$ ) located $0.5 \mathrm{~m}$ apart, along a $25 \mathrm{~m}$ transect. Sampling was repeated in 1968 and 1969 . Herbage yields were determined by clipping five $9.6 \mathrm{ft}^{2}$ plots to ground level at each site. Range condition at each site was judged following the classification of McLean and Marchand (1968).

This study is an attempt to evaluate the effects of complete rest on four exclosures in the ponderosa pine zone and three in the rough fescue grasslands (Fig. 1). Tisdale (1947) has described the grassland zone in southern British Columbia.

Plant nomenclature follows Hitchcock et al. (1955-1969). The soils are classified according to the Canadian classification (Soil Survey Committee of Canada, 1968). American classification equivalents were determined as closely as possible and are given in brackets. The plant community nomenclature follows that of McLean (1970) and is essentially that used by Daubenmire (1970) in Washington. 


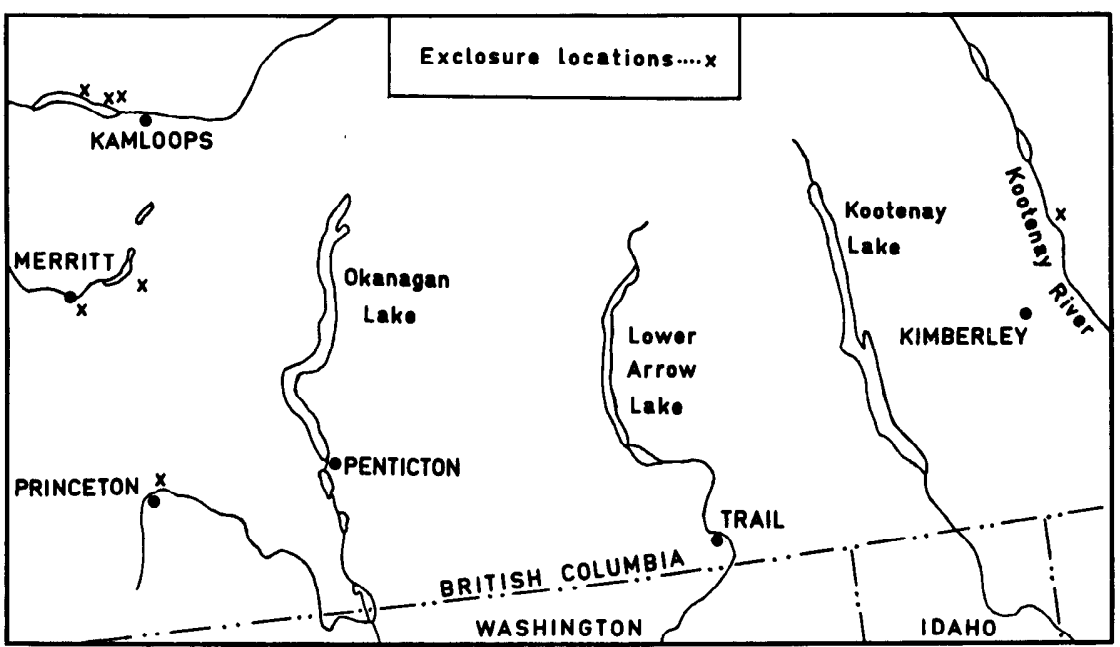

Fig. 1. Map of southern British Columbia showing exclosure locations.

\section{Results}

Fescue Grassland Zone

\section{Lundbum exclosure}

This site is located in the rough fescue-eriogonum (Festuca scabrellaEriogonum heracleoides) habitat type about 4 miles southeast of Merritt. The soil is a medium textured Dark Gray Chernozem (Haploboroll). The one-half acre ex- closure was fenced in 1931. It lies on a level, exposed hilltop at 3,500 feet elevation. The area was and is subjected to heavy spring and fall grazing.

Records at time of fencing indicate that the site was dominated by Sandberg bluegrass (Poa sandbergii), low pussytoes (Antennaria dimorpha), and dwarf fleabane (Erigeron compositus). Other com- mon species were cheatgrass (Bromus tectorum), Junegrass (Koeleria cristata), and yarrow (Achillea millefolium).

Twenty-nine years after fencing (Table 1) there was five times the foliage cover of bluebunch wheatgrass (Agropyron spicatum), rough fescue and Kentucky bluegrass (Poa pratensis) inside the exclosure as compared with that outside. There was also a marked decrease in the amount of Sandberg bluegrass, low pussytoes, and dwarf fleabane. Over the next 8 years there was a continued increase in the cover of bluebunch wheatgrass, rough fescue and Kentucky bluegrass. At the same time there was a continued decrease in the frequency of Sandberg bluegrass, low pussytoes, and cheatgrass. During this period there was relatively little change in the vegetation of the grazed area.

Average herbage production during the period 1959 to 1966 showed a $\mathbf{9 8 \%}$ greater yield inside the exclosure compared with outside (Table 2).

Table 1. Changes in canopy cover $(\%)$ and frequency $(\%)$ of selected species on three exclosure sites in the rough fescue zone, 1959 to 1968 . (The symbol $T$ represents coverage values less than $.6 \%$ ).

\begin{tabular}{|c|c|c|c|c|c|c|c|c|c|c|c|c|}
\hline \multirow[b]{3}{*}{ Species } & \multicolumn{4}{|c|}{ Lundbum } & \multicolumn{4}{|c|}{ Hamilton } & \multicolumn{4}{|c|}{ East Mara } \\
\hline & \multicolumn{2}{|c|}{ Inside } & \multicolumn{2}{|c|}{ Outside } & \multicolumn{2}{|c|}{ Inside } & \multicolumn{2}{|c|}{ Outside } & \multicolumn{2}{|c|}{ Inside } & \multicolumn{2}{|c|}{ Outside } \\
\hline & 1960 & 1968 & 1960 & 1968 & 1960 & 1968 & 1960 & 1968 & 1959 & 1968 & 1959 & 1968 \\
\hline \multicolumn{13}{|l|}{ Decreasers } \\
\hline Bluebunch wheatgrass & $13 / 44$ & $19 / 50$ & $3 / 36$ & $6 / 30$ & $17 / 72$ & $15 / 50$ & $5 / 22$ & $4 / 20$ & $13 / 42$ & $7 / 34$ & $11 / 34$ & $7 / 40$ \\
\hline Rough fescue & $25 / 54$ & $39 / 70$ & $4 / 26$ & $\mathrm{~T} / 2$ & $26 / 70$ & $52 / 90$ & $1 / 2$ & $1 / 4$ & $76 / 100$ & $76 / 100$ & $7 / 30$ & $1 / 12$ \\
\hline \multicolumn{13}{|l|}{ Increasers } \\
\hline $\begin{array}{l}\text { Balsamroot } \\
\text { Dwarf fleabane }\end{array}$ & $1 / 8$ & $\mathrm{~T} / 2$ & $7 / 52$ & $9 / 74$ & 00 & $\mathrm{~T} / 6$ & $6 / 74$ & $4 / 20$ & $8 / 36$ & $8 / 42$ & $2 / 22$ & $2 / 14$ \\
\hline Junegrass & $15 / 92$ & $15 / 68$ & $15 / 98$ & $22 / 92$ & $16 / 92$ & $17 / 72$ & $3 / 14$ & $13 / 78$ & $21 / 82$ & $13 / 70$ & $50 / 100$ & $40 / 94$ \\
\hline Kentucky bluegrass & $13 / 28$ & $18 / 48$ & $\mathrm{~T} / 4$ & $3 / 8$ & & & & & & & & \\
\hline Low pussytoes & $1 / 20$ & $\mathrm{~T} / 4$ & $7 / 88$ & $9 / 68$ & 00 & 00 & $2 / 44$ & $11 / 72$ & & & & \\
\hline Pasture sage & & & & & & & & & 00 & 00 & $2 / 24$ & $1 / 16$ \\
\hline Rockcress & & & & & & & & & $\mathrm{T} / 8$ & $\mathrm{~T} / 2$ & $1 / 56$ & $2 / 34$ \\
\hline Sandberg bluegrass & $10 / 68$ & $4 / 30$ & $38 / 98$ & $38 / 100$ & $12 / 98$ & $9 / 66$ & $36 / 100$ & $42 / 100$ & $10 / 82$ & $6 / 54$ & $23 / 98$ & $21 / 88$ \\
\hline Umber pussytoes & 00 & 00 & $\mathrm{~T} / 2$ & $5 / 14$ & $5 / 56$ & $2 / 14$ & $\mathrm{~T} / 2$ & $5 / 30$ & & & & \\
\hline Yarrow & $6 / 48$ & $11 / 70$ & $7 / 54$ & $7 / 58$ & $10 / 90$ & $18 / 92$ & $3 / 30$ & $5 / 54$ & & & & \\
\hline
\end{tabular}

Invaders

Cheatgrass

Dandelion

$4 / 24 \quad 1 / 4 \quad 2 / 26 \quad 3 / 12$

Stickseed

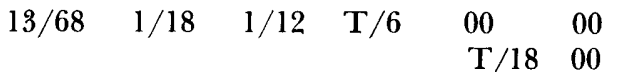

$\mathrm{T} / 2 \quad 5 / 48$

$3 / 94 \quad 10 / 72$ 

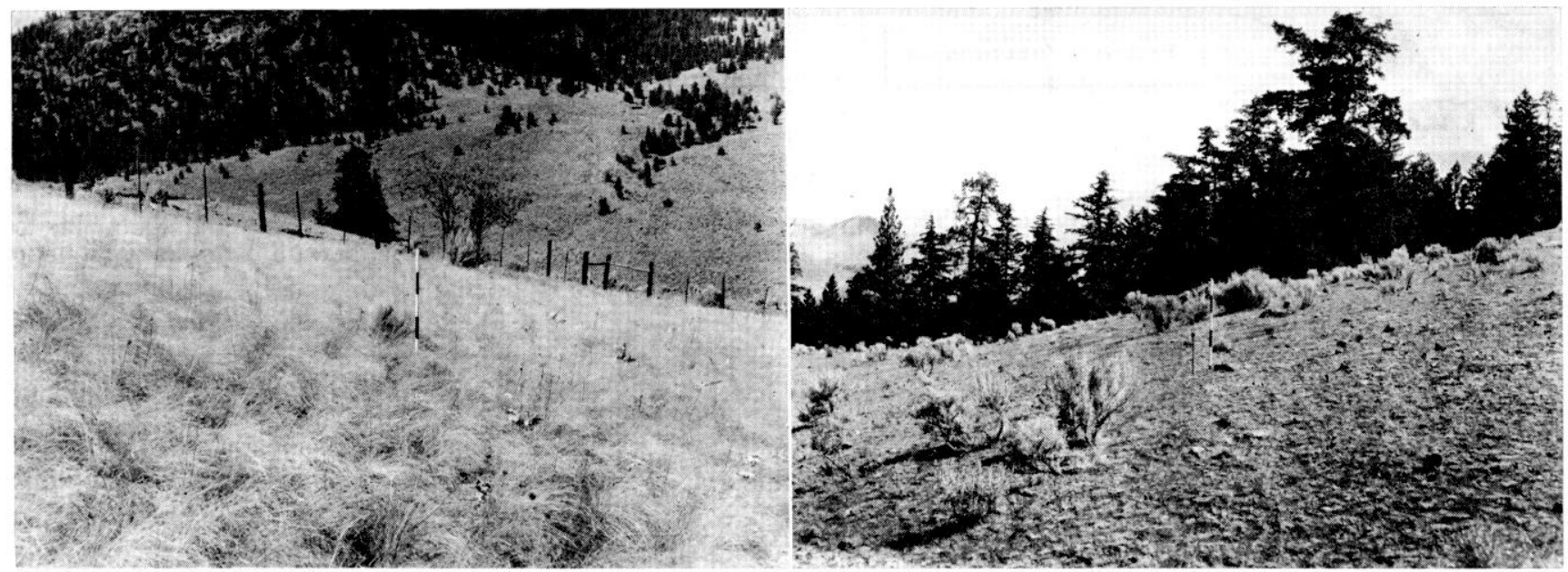

FIG. 2. East Mara exclosure, protected area (left) as contrasted with grazed range (right).

\section{Hamilton exclosure}

This $2 \frac{1}{2}$ acre exclosure, about 16 miles east of Merritt, is located in the rough fescue-eriogonum habitat type. The soil is a Black Chernozem (Haploboroll), sandy loam in texture. The exclosure was fenced in 1931. It lies on a $4 \%$ southeasterly slope at 3,800 feet elevation. The exclosure is about 150 yards from a lake, and the area was heavily grazed prior to 1931 . The vegetation in this general area was badly damaged by pocket gophers during the drought of the 1930's.

Records at time of fencing indicate that the site was dominated by Sandberg bluegrass, low and umber pussytoes (Antennaria umbrinella), and dwarf fleabane. Junegrass and yarrow were common but only a small amount of bluebunch wheatgrass was present.

Twenty-nine years after fencing

Table 2. Herbage yields (lb./acre, dry weight) on three exclosure sites in the rough fescue-eriogonum habitat type, 1959 to 1966.

\begin{tabular}{|c|c|c|c|c|c|c|}
\hline \multirow[b]{2}{*}{ Year } & \multicolumn{2}{|c|}{ Lundbum } & \multicolumn{2}{|c|}{ Hamilton } & \multicolumn{2}{|c|}{ East Mara } \\
\hline & Inside & Outside & Inside & Outside & Inside & Outside \\
\hline 1959 & - & - & 872 & 510 & 1150 & 398 \\
\hline 1960 & 988 & 400 & 890 & 564 & 1702 & 854 \\
\hline 1961 & 1156 & 488 & 772 & 368 & 924 & 526 \\
\hline 1963 & - & - & - & - & 834 & 618 \\
\hline 1964 & 802 & 394 & - & - & 958 & 426 \\
\hline 1965 & 796 & 438 & - & - & 762 & 406 \\
\hline 1966 & 832 & 594 & 578 & 354 & - & - \\
\hline Avg. & 915 & 463 & 778 & 449 & 1055 & 538 \\
\hline
\end{tabular}

(Table 1) there was a much greater cover of rough fescue, bluebunch wheatgrass, and Junegrass inside the exclosure, compared to an abundance of dwarf fleabane and Sandberg bluegrass outside. A review of earlier observations suggests that vegetation on the grazed area had not changed appreciably. Nine years later the cover of rough fescue inside the exclosure had doubled, while the proportion of umber pussytoes, dandelion (Taraxacum officinale), and Sandberg bluegrass had decreased. There were indications of further deterioration in the grazed range during the same period with an increase in both low and umber pussytoes.

The 4-year average herbage yield shows a $73 \%$ greater production inside the fence as compared with outside following 32 years of protection (Table 2).

\section{East Mara exclosure}

This exclosure is located in a stand of the rough fescue-eriogonum habitat type about 3 miles west of Kamloops. The soil is a mediumtextured Black Chernozem (Haploboroll). The exclosure is one-half acre in size and was fenced in 1938. It lies on a $20 \%$ northeast slope at 2,800 feet elevation. The area was heavily grazed up to 1935 and is located about 200 yards from a homestead which was occupied until the mid 1920's. At the time of fencing the area was dominated by Sandberg bluegrass, umber pussytoes, and Junegrass with some big sagebrush (Artemisia tridentata) and gray rabbitbrush (Chrysothamnus nauseosus). A few unthrifty bluebunch wheatgrass and rough fescue plants were also present.

Observations made in 1940 and 1950 suggest that considerable improvement took place in the first 10 years after fencing. There was a marked increase in bluebunch wheatgrass and decrease in Sandberg bluegrass. Between 1950 and 1959, there was a striking increase in the proportion of rough fescue present.

The data support these observations, for 21 years after fencing (Table 1) the foliage cover of rough fescue was ten times greater inside the exclosure than in the grazed area (Fig. 2). In addition, the proportions of balsamroot (Balsamor- 
Table 3. Changes in canopy cover $(\%)$ and frequency $(\%)$ of selected species on three exclosure sites in the ponderosa pine zone 1959 to 1970 . (The symbol $T$ represents coverage values less than .6\%).

\begin{tabular}{|c|c|c|c|c|c|c|c|c|c|c|c|c|}
\hline \multirow[b]{3}{*}{ Species } & \multicolumn{4}{|c|}{ Skookumchuck } & \multicolumn{4}{|c|}{ West Mara } & \multicolumn{4}{|c|}{ Dewdrop } \\
\hline & \multicolumn{2}{|c|}{ Inside } & \multicolumn{2}{|c|}{ Outside } & \multicolumn{2}{|c|}{ Inside } & \multicolumn{2}{|c|}{ Outsidc } & \multicolumn{2}{|c|}{ Inside } & \multicolumn{2}{|c|}{ Outside } \\
\hline & 1960 & 1970 & 1960 & 1970 & 1959 & 1968 & 1959 & 1968 & 1959 & 1968 & 1959 & 1968 \\
\hline \multicolumn{13}{|l|}{ Decreasers } \\
\hline Bluebunch wheatgrass & $25 / 72$ & $55 / 96$ & $7 / 26$ & $13 / 62$ & $36 / 58$ & $45 / 80$ & $8 / 32$ & $12 / 72$ & $58 / 98$ & $57 / 100$ & $28 / 74$ & $27 / 74$ \\
\hline Rough fescue & $6 / 36$ & $20 / 48$ & 00 & $\mathrm{~T} / 2$ & & & & & & & & \\
\hline \multicolumn{13}{|l|}{ Increasers } \\
\hline $\begin{array}{l}\text { Big sagebrush } \\
\text { Junegrass }\end{array}$ & & & & & $34 / 74$ & $31 / 72$ & $38 / 82$ & $37 / 78$ & & & $r(40$ & 0 \\
\hline Low pussytoes & $10 / 94$ & $\mathrm{~T} / 24$ & $\begin{array}{l}17 / 90 \\
26 / 98\end{array}$ & $\begin{array}{r}20 / 94 \\
8 / 58\end{array}$ & $\mathrm{~T} / 20$ & & & $5 / 46$ & $2 / 18$ & $5 / 46$ & $5 / 40$ & $4 / 30$ \\
\hline Needleandthread & $17 / 74$ & $1 / 4$ & $\begin{array}{r}20 / 90 \\
4 / 68\end{array}$ & $\begin{array}{r}8 / 58 \\
34 / 98\end{array}$ & $1 / 22$ & $1 / 2$ & $1 / 10$ & & $1 / 4$ & $2 / 6$ & $17 / 36$ & $17 / 66$ \\
\hline Pasture sage & & & & & $\mathrm{T} / 2$ & $2 / 34$ & $3 / 12$ & $\mathrm{~T} / 2$ & & & & \\
\hline Gray rabbitbrush & & & & & & & & & $1 / 4$ & $1 / 6$ & $5 / 30$ & $16 / 70$ \\
\hline Sandberg bluegrass & $17 / 100$ & $5 / 50$ & $26 / 98$ & $10 / 94$ & $15 / 92$ & $22 / 96$ & $27 / 98$ & $39 / 96$ & & & & \\
\hline Total no. species & 18 & 12 & 14 & 13 & & & & & 19 & 22 & 22 & 26 \\
\hline
\end{tabular}

rhiza sagittata) and bluebunch wheatgrass were also greater inside. On the other hand, the cover of Junegrass, Sandberg bluegrass and frequency of pasture sage (Artemisia frigida), stickseed (Lappula redowskii), and rockcress (Arabis holboellii) was less inside than outside. The coverage data also indicate relatively little change in the vegetation inside the exclosure over the past 9 years. Outside the exclosure, however, the range declined in condition. There was a decrease in the cover of rough fescue and bluebunch wheatgrass and increase in needleandthread (Stipa comata), umber pussytoes, and dandelion.

Herbage yields show an increase of $97 \%$ inside in contrast to outside the exclosure following 21 years of protection (Table 2).

\section{Ponderosa Pine Zone}

\section{Skookumchuck exclosure}

This site, which is 25 miles north of Kimberley, belongs in the ponderosa pine-bluebunch wheatgrass habitat type. The soil is a coarse textured Dark Brown Chernozem (Haplustoll). The 1-acre exclosure was fenced in 1950. It is located at 2,700 feet elevation on a level, stony river terrace in a grassland opening surrounded by open stands of ponderosa pine (Pinus ponder- osa) in slight depressions. The area had received heavy spring and fall grazing for many years. In 1950 the grazing management was adjusted to reduce the stocking rate and to delay the start of grazing in the spring.

Records taken by the B. C. Forest Service at the time of fencing indicate that the area was dominated by Sandberg bluegrass and low pussytoes with smaller amounts of Junegrass and needleandthread. There appeared to be little bluebunch wheatgrass and virtually no rough fescue on the site.

Ten years after fencing there was considerably more bluebunch wheatgrass and rough fescue inside the exclosure as compared with the grazed area (Table 3) and much less low pussytoes and Sandberg bluegrass. By the end of the next 9 years there was a still greater increase in the amount of bluebunch wheatgrass and rough fescue inside the exclosure and a marked decrease in Sandberg bluegrass, needleandthread, and low pussytoes. There was also some improvement on the grazed area, as indicated by an increase in bluebunch wheatgrass and rough fescue and decrease in low pussytoes.

Average herbage production (Table 4) indicated a $60 \%$ greater yield inside the cxclosure as com- pared with that outside 15 years after fencing.

\section{West Mara exclosure}

This site is located in the ponderosa pine-bluebunch wheatgrass habitat type about 3 miles west of Kamloops. The soil is a Dark Brown (Haplustoll) sandy loam.

The one-half acre exclosure was fenced in 1936 and is located on a slight west-facing slope at 2,100 feet elevation. The area was heavily grazed up to 1935 and lies about 100 yards from a homestead which was occupied until the mid 1920's. It is now used as spring and fall range.

Records taken at time of fencing indicate that the area was dominated by big sagebrush, low pussytoes and Sandberg bluegrass with a small amount of bluebunch wheatgrass present. No trees occurred in the immediate area of the exclosure then nor have any become established.

Data recorded in 1959 (Table 3), 23 years after fencing, show that bluebunch wheatgrass plants inside the exclosure had over four times the foliage cover of those plants outside. Sandberg bluegrass on the other hand, had much greater coverage outside as compared with inside. The poorer range condition outside was also reflected in the 

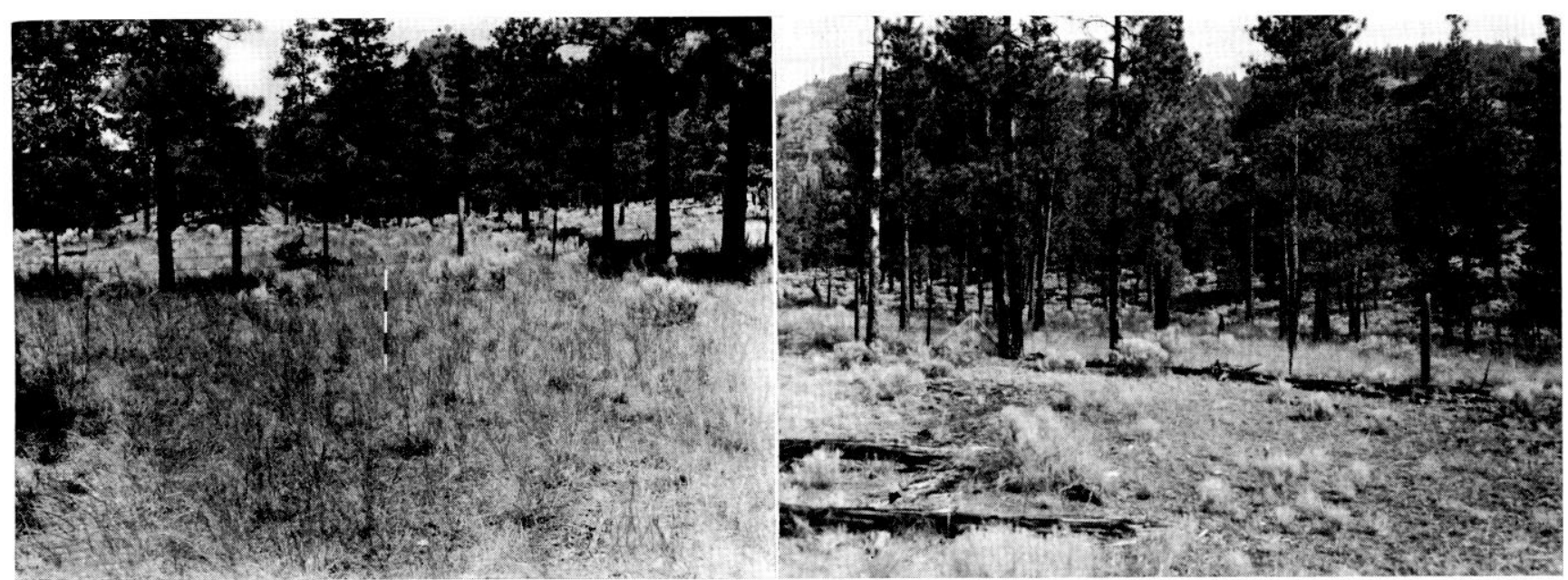

Fig. 3. Dewdrop exclosure, protected area (left) contrasted with grazed range (right).

greater frequency of low pussytoes. In the 9 years following 1959 there was a marked increase in bluebunch wheatgrass both inside and outside the exclosure, an increase in pasture sage inside and a decrease in low pussytoes. Big sagebrush remained essentially unchanged in amount both inside and outside.

The average herbage yield (Table 4) indicated a $160 \%$ increase in production inside the exclosure over that outside after 23 years of protection.

\section{Dewdrop exclosure}

The vegetation on this site, about 3 miles northwest of Tranquille, belongs to the ponderosa pine-bluebunch wheatgrass habitat type. The soil is a Dark Gray Chernozem
(Haploboroll) sandy loam. This one-half acre exclosure was fenced in 1935 and is located on a $4 \%$ south-facing slope at 2,100 feet elevation. The area has been heavily used as spring and fall range for about 40 years and was homesteaded prior to that time. It supports an open stand of scrubby ponderosa pine (height, 50 feet; age, 170 years).

At the time of fencing the area was dominated by an open stand of ponderosa pine with an undercover of rabbitbrush, needleandthread, Junegrass, and low pussytoes. Some bluebunch wheatgrass was also present.

General observations and limited quadrat data obtained in 1949 and 1959 suggest that the greatest im- provement took place in the 13 years following 1936 and continued to a lesser extent over the next 10 years. During the initial period there was a marked increase in bluebunch wheatgrass. There was also a decrease in needleandthread, low pussytoes, and rabbitbrush (Fig. 3).

The coverage data (Table 3) suggest no important changes in the next 10 years either inside or outside the exclosure. There was, however, an increase in the amount of rabbitbrush outside and of Junegrass inside.

The average herbage yield (Table 4) indicates a $124 \%$ increase in production inside the exclosure as compared with outside.

Table 4. Herbage yields (lb./acre, dry weight) on four exclosure sites in the ponderosa pine zone, 1959 to 1969.

\begin{tabular}{|c|c|c|c|c|c|c|c|c|c|c|}
\hline \multirow[b]{2}{*}{ Year } & \multicolumn{4}{|c|}{ Skookumchuck } & \multicolumn{2}{|c|}{ West Mara } & \multicolumn{2}{|c|}{ Princeton } & \multicolumn{2}{|c|}{ Dewdrop } \\
\hline & Inside & Outside & Inside & Outside & Inside & Outside & Inside & Outside & Inside & Outside \\
\hline 1959 & - & - & - & - & 372 & 124 & - & - & - & - \\
\hline 1960 & 484 & 150 & - & - & 476 & 160 & 426 & 272 & 380 & 164 \\
\hline 1961 & 462 & 218 & - & - & - & - & 1324 & 748 & 360 & 168 \\
\hline 1962 & 424 & 238 & - & - & - & - & - & - & - & - \\
\hline 1963 & 390 & 272 & - & - & 472 & 198 & 640 & 492 & 214 & 104 \\
\hline 1964 & 296 & 126 & - & - & 344 & 124 & 714 & 656 & 196 & 94 \\
\hline 1965 & - & - & 306 & 264 & 406 & 194 & - & - & 308 & 125 \\
\hline 1966 & - & - & 408 & 266 & - & - & - & - & - & - \\
\hline 1967 & - & - & 294 & 151 & - & - & - & - & - & - \\
\hline 1968 & - & - & 452 & 151 & - & - & - & - & - & - \\
\hline 1969 & - & - & 674 & 448 & - & - & - & - & - & - \\
\hline Avg. & 411 & 201 & 427 & 257 & 414 & 160 & 776 & 542 & 292 & 131 \\
\hline
\end{tabular}


Table 5. Number of surviving plants of three range species inside the Dewdrop exclosure thirty-three years after tagging.

\begin{tabular}{lccccc}
\hline \hline & \multicolumn{5}{c}{ Year of observation } \\
\cline { 2 - 6 } \multicolumn{1}{c}{ Species } & 1936 & 1947 & 1956 & 1963 & 1969 \\
\hline Bluebunch wheatgrass & 10 & 9 & 9 & 8 & 7 \\
Junegrass & 10 & 5 & 4 & 3 & 1 \\
Rabbitbrush & 10 & NR & 1 & 1 & 1 \\
\hline
\end{tabular}

As a special study in this exclosure, ten well-established plants, presumably 2 or more ycars old, of bluebunch wheatgrass, Junegrass and rabbitbrush were tagged in 1936. The object was to see how long the plants lived (Table 5).

The clumps of wheatgrass listed as surviving have shifted and broken up greatly over the years and the centers have died.

\section{Princeton exclosure}

This exclosure is about one mile north of Princeton in the ponderosa pine zone. The soil is a Dark Gray Chernozem (Haploboroll) sandy loam. The area was fenced in 1937 by the Canada Department of Transport. The area had been heavily grazed for at least 50 years and still is heavily used. It is located at 2,200 feet elevation on a level, stony river terrace. No data are available for the vegetation on the area at time of fencing but it is thought to have been dominated by cheatgrass as at present.

Records taken in 1960 (23 years after fencing) indicate more bluebunch wheatgrass and silky lupine inside the exclosure as compared with the grazed area. There was also less western needlegrass (Stipa occidentalis), low pussytoes, shaggy fleabane (Erigeron pumilis), sixweeks fescue (Festuca occidentalis), and cheatgrass insidc the cxclosurc.

Ten years later the bluebunch wheatgrass had decreased and cheatgrass increased inside the exclosure because of gopher activity. Ground disturbance by gophers was greater inside the exclosure presumably as a result of protective cover for the rodents provided by old plant growth.

\section{Discussion}

Only approximate lengths of time for recovery in condition of a range can be assigned to these exclosures because of slowness of change and infrequency of observations. Even these data have proved useful as guidelines for range improvement projects and for interpreting the reaction of various species to grazing. In the rough fescue zone the Lundbum and Hamilton exclosures improved from poor to good condition within 30 years and to excellent condition within the next 10 years. The East Mara exclosure progressed from fair to excellent condition within 20 years. Bluebunch wheatgrass recovered within the first 10 years while rough fescue made its greatest gains in the second decade.

In the ponderosa pine zone the Skookumchuck exclosure advanced from poor to fair in less than 10 years and to excellent condition within 20 years. There has also been some improvement in the condition of the grazed area as a result of improved range management. The Dewdrop exclosure progressed from fair to good in 13 years but reached excellent condition in less than 10 years more. The West Mara and Princeton exclosures advanced from poor to fair condition within 23 years. West Mara approached good condition in $\mathbf{3 3}$ years. Princeton, however, retrogressed to poor condition in the next 10 years. This deterioration is an example of what happens to some exclosures where they are surrounded by large overgrazed areas which favor destructive populations of rodents or other animals.

On all sites most improvement in the stands came about in the last 10 years of protection, with relatively little improvement during the first 10 years. After 25 years of protection, increases in forage yields of 98,73 , and $97 \%$ occurred on the rough fescue sites, largely due to increases in the abundance of climax grasses. Increased yields inside the three ponderosa pine exclosures as compared with the adjacent grazed range were in the order of 60,160 , and $124 \%$.

The main species to benefit from grazing protection on the fescue grassland sites were bluebunch wheatgrass and rough fescue. There was also some increase in yarrow on the three sites and increases in balsamroot and Kentucky bluegrass on the one site each, on which they occurred. The main species to decrease under protection were Sandberg bluegrass, low pussytoes, umber pussytoes, dwarf fleabane and gray rabbitbrush. Annuals such as falseflax (Camelina microcarpa), stickseed, pink microsteris (Microsteris gracilis), and cheatgrass were common invaders on the adjacent heavily used range.

In the ponderosa pine zone, bluebunch wheatgrass increased with protection on all four sites, rough fescue on the two sites, and silky lupine (Lupinus sericeus) on the one site on which they were found. The site containing lupine was grazed heavily in the spring and there was little opportunity for that species to set seed. Sandberg bluegrass decreased in two exclosures and increased in the third; the latter presumably as a result of early spring grazing which reduced seed production. Low pussytoes, gray rabbitbrush, pasture sage, western needlegrass, and shaggy fleabane decreased with protection. Six-weeks fescue, stickseed, and pink microsteris were invaders on adjacent heavily used range. Junegrass increased with protection on sites that had advanced from poor to fair condition. It decreased, however, on sites which reached excellent condition. The species is fairly high in livestock prefercnce and is 
one of the first species to increase when range improvement starts.

The differences among exclosures in time required for improvement are no doubt related to soils, climate, competing species, and available seed source. The longer time period required to progress from poor to fair condition than from fair to good has important implications from both ecological and management standpoints. Long periods of complete rest are not usually an economical acceptable form of range rehabilitation. One alternative is to graze only during the season that is least damaging to the herbage; i.e. moderate fall or winter grazing. The other is to seed to tame grasses, depending on cost in relation to expected yield increases.

\section{Literature Cited}

Daubenmire, R. 1959. A canopycoverage method of vegetational analysis. Northwest Sci. 33:43-66.

Daubenmire, R. 1970. Steppe vegetation of Washington. Wash. Agr. Exp. Sta. Tech. Bull. 62.131 p.

Hitchcock, C. L., A. Cronquist, M. OWNBEy, AND J. W. Thompson. 1955-69. Vascular plants of the
Pacific Northwest. Univ. Washington Press, Seattle. Part 1, 914 p.; Part 2, 597 p.; Part 3, 614 p.; Part 4, 510 p.; and Part 5, 343 p.

McLean, A., and L. S. Marchand. 1968. Grassland ranges in the southern interior of British Columbia. Can. Dep. Agr. Pub. 1319. 28 p.

McLean, A. 1970. Plant communities of the Similkameen Valley, British Columbia and their relationships to soils. Ecol. Monogr. 40:403-424.

Soll Survey Committee of Canada. 1968. Proc. Seventh Nat. Meeting, Can. Dep. Agr., Ottawa. 216 p.

Tisdale, E. W. 1947. The grasslands of southern interior British Columbia. Ecology, 28:346-382. 